\author{
Jerzy Jaskiernia \\ Uniwersytet Jana Kochanowskiego w Kielcach \\ Górnośląska Wyższa Szkoła Handlowa im. Wojciecha Korfantego w Katowicach
}

\title{
ROLA PARLAMENTÓW NARODOWYCH W PROCESIE INTEGRACJI EUROPEJSKIEJ PO TRAKTACIE Z LIZBONY I KONIECZNE ZMIANY W PRAWIE PARLAMENTARNYM
}

DOI: http://dx.doi.org/10.12775/TSP-W.2013.004

\section{UWAGI WPROWADZAJĄCE}

Problematyka parlamentaryzmu uzyskała w ostatnich dekadach nowy kontekst: wymiar zewnętrzny ${ }^{1}$. Analizowane są zwłaszcza skutki procesu integracji europejskiej dla pozycji ustrojowej parlamentów narodowych². Członkostwo państwa w UE niesie bowiem nowe wyzwania dla ukształtowania ustrojowej pozycji parlamentów narodowych ${ }^{3}$. Przekazanie znaczących kompetencji ustawodawczych na rzecz organów unijnych rodzi pytanie, czy nie mamy tu do czynienia z marginalizacją znaczenia parlamentów narodowych w zakresie funkcji ustawodawczej4. Istotne jest też to, jaką rolę mają parlamenty narodowe w systemie instytucjonalnym UE - stało się to przedmiotem obrad XXIV Kongresu Międzynarodowej

${ }^{1}$ Zob. M. MacCarthaig, Conceptualizing the Role of National Parliaments in the EU System of Governance, "Administration" 2006, nr 3, s. 71.

2 Por. M.V. Agostini, The Role of the National Parliaments in the Future EU, "The International Spectator" 2001, nr 4, s. 34; F. Duina, M.J. Oliver, National Parliaments in the European Union: Are There any Benefits to Integration?, "European Law Journal” 2005, nr 2, s. 176.

${ }^{3}$ Por. National Parliaments and the European Union: the Constitutional Challenge for the Oirechtas and other Member State Legislatures, red. G. Barrett, Clarus, Dublin 2008.

${ }^{4}$ Zob. J. Jaskiernia, Członkostwo Polski w UE a problem nowelizacji Konstytucji RP, Wydawnictwo Naukowe „Scholar”, Warszawa 2004, s. 35. 
Federacji Prawa Europejskiego (International Federation for the European Law FIDE), odbytego w Madrycie w 2010 r. ${ }^{5}$ Oferowane są klasyfikacje funkcji parlamentów narodowych w systemie politycznym Unii ${ }^{6}$. Podnoszony jest też problem efektywności parlamentarnej reprezentacji w unijnych procesach decyzyjnych ${ }^{7}$. W związku z akcesją Polski do Unii Europejskiej parlament narodowy interesuje nas już nie tylko jako wyraz sprawowania władzy przez Suwerena w ramach form demokracji pośredniej, lecz także musi być dostrzegany w szerszym mechanizmie wspólnotowego procesu podejmowania decyzji ${ }^{8}$. Proces ten jest jednak zdominowany przez organy władzy wykonawczej (rządy), co jest jedną z zasadniczych przyczyn zjawiska „,deficytu demokracji”. Istotnym w związku z tym problemem staje się poszukiwanie sposobów większego oddziaływania parlamentu narodowego na wspólnotowe procesy decyzyjne ${ }^{10}$.

Problem ten nabrał szczególnego znaczenia w wyniku wejścia w życie Traktatu z Lizbony (1 XII 2009 r.), który wzmocnił rolę parlamentów narodowych W unijnym procesie decyzyjnym ${ }^{11}$, eksponując po raz pierwszy w sposób tak spektakularny demokratyczne wartości, na jakich ma być oparta Unia ${ }^{12}$. Uzyskały one prawo do badania zgodności aktów ustawodawczych Unii z zasadą pomocni-

5 Zob. The Role of National Parliaments in the European Union, red. G.C. Rodriguez Iglesias, Servicio de Publicaciones de la Universidad Complutense de Madrid, Madrid 2010. Na Kongresie tym przedstawiony został m.in. raport M. Wyrzykowskiego, R. Puchty i M Ziólkowskiego pt. Rola parlamentów narodowych w Unii Europejskiej.

${ }^{6}$ Zob. T. Raunio, C. Sprungk, National Parliaments in the EU, "Journal of European Integration" 2011, nr 3, s. 307.

7 Zob. D.M. Farrell, R. Scully, Representing Europe's Citizens? Electoral Institutions and the Failure of Parliamentary Representation, Oxford University Press, Oxford 2007, s. 23.

8 Zob. R. Grzeszczak, Miejsce parlamentów narodowych $w$ architekturze instytucjonalnej Wspólnoty Europejskiej i UE - scenariusze zmian, [w:] Unia Europejska w dobie reform. Konwent Europejski - Traktat Konstytucyjny - Biała Księga w sprawie rzq̨dzenia Europa, VIII Ogólnopolska Konferencja Prawnicza, Toruń 27-28 marca 2003 r., red. C. Mik, Dom Organizatora TNOiK, Toruń 2004, s. 209.

9 Zob. J. Jaskiernia, Rozwój instytucjonalny Unii Europejskiej a problem ,deficytu demokracji”, [w:] Forum Spraw Publicznych, VII Konferencja, Przyszłość Unii Europejskiej, 10 czerwca 2006, LAM - Wydawnictwo Akademii Finansów, Warszawa 2006, s. 17.

${ }^{10}$ Zob. K. Neunreither, The Democratic Deficit of the European Union: Towards Closer Cooperation between the European Parliament and National Parliaments, "Government and Opposition" 1994, nr 3, s. 302.

11 Zob. J. Jaskiernia, Traktat z Lizbony jako podstawa rozwoju Unii Europejskiej w formie jednolitej organizacji międzynarodowej, „Europejski Przegląd Prawa i Stosunków Międzynarodowych" 2009, nr 3-4, s. 171.

12 Zob. S. Bredt, Prospects and Limits of Democratic Governance in the EU, "European Law Journal” 2011, nr 1, s. 37. 
czości $^{13}$, na podstawie mechanizmu ,wczesnego ostrzegania” ${ }^{14}$. Ma to być istotna przesłanka do ograniczenia ,deficytu demokratycznego” w Unii Europejskiej ${ }^{15}$ i zwiększenia jej legitymacji demokratycznej ${ }^{16}$. Wiąże się ona bowiem z rolą, jaką odgrywają w procesie decyzyjnym zarówno Parlament Europejski, jak i parlamenty narodowe ${ }^{17}$. Nie ulega więc wątpliwości, że rola parlamentów narodowych w UE uległa zmianie ${ }^{18}$. Zachodzi jednak potrzeba badania, w jakim zakresie te nowe uprawnienia faktycznie zwiększyły rolę parlamentów narodowych w unijnym procesie decyzyjnym ${ }^{19}$.

\section{EWOLUCJA ROLI PARLAMENTÓW NARODOWYCH W PROCESACH DECYZYJNYCH UNII EUROPEJSKIEJ}

Rola parlamentów narodowych w unijnych procesach decyzyjnych uległa interesującej ewolucji ${ }^{20}$. W Deklaracji nr 13 dotyczacej roli parlamentów narodowych w Unii Europejskiej, dołączonej do Traktatu z Maastricht (1992) uznano, że pierwszorzędne znaczenie ma włączenie parlamentów narodowych w działalność Unii. Chodziło w szczególności o zintensyfikowanie wymiany infor-

${ }^{13}$ Zob. R. Passos, Recent Development Concerning the Role of National Parliaments in the European Union, "ERA: Scripta Iuris Europei” 2008, nr 1, s. 27.

14 Por. A. Cygan, ,Collective” Subsidiarity Monitoring by National Parliaments after Lisbon: the Operation of the Early Warning Mechanism [w:] The Treaty of Lisbon and the Future of European Law and Policy, red. M. TRybus, L. Rubini, Edward Edgar, Cheltenham 2012.

15 Zob. J. Jaskiernia, Traktat z Lizbony a problem „,deficytu demokratycznego” w Unii Europejskiej, Zeszyty Naukowe Wyższej Szkoły Informatyki, Zarządzania i Administracji w Warszawie, 2010, nr 2, s. 37.

16 Zob. J. Jaskiernia, Traktat z Lizbony a problem legitymizacji demokratycznej Unii Europejskiej [w:] Prawowitość czy zgodność z prawem: Legitymacja władzy w państwach demokratycznych, red. A. Preisner, Beta-Druk, Wrocław 2010, s. 294.

17 Zob. J. Jaskiernia, Dual Legitimacy of the European Union after the Treaty of Lisbon, Zeszyty Naukowe Wyższej Szkoły Informatyki, Zarządzania i Administracji w Warszawie, 2011, z. 4, s. 7-24.

18 Por. R. Hrbek, The European Union after Lisbon: Constitutional Basis, Economic Order and External Action of the European Union, Springer, Berlin 2012.

19 Zob. P. Kiiver, The Early Warning System for the Principle of Subsidiarity: Constitutional Theory and Empirical Reality, Routlegde, Abington 2012, s. 127.

20 Por. P. Kiiver, The National Parliaments in the European Union: a Critical View on EU Constitution-Building, Kluwer Law International, The Hague 2006, s. 29 i n.; J. O'Brennan, T. Raunio, National Parliaments within the Enlarged European Union: from "Victims" of Integration to Competitive Actors?, Routledge, London 2007, s. 39 i n.; National Parliaments and European Democracy: a Bottom-Up Approach to European Constitutionalism, ed. O. Tans, C. Zoethout, J. Peters, Europa Law, Groningen 2007. 
macji między parlamentami narodowymi a parlamentem europejskim, a także o zapewnienie warunków do odbywania regularnych spotkań między parlamentarzystami krajowymi i europejskimi, zainteresowanymi podobną problematyką. Rządy państw członkowskich zostały zobowiązane do przedstawiania parlamentom krajowym propozycji legislacyjnych Komisji Europejskiej - z odpowiednim wyprzedzeniem, pozwalającym na zapoznanie się z ich treścią i ewentualne zajęcie stanowiska. Postanowienia te doczekały się jednak tylko fragmentarycznej realizacji. Co prawda propozycje Komisji były przekazywane organom parlamentarnym, ale tylko w niektórych państwach dotyczyło to spraw związanych z II i III filarem. Ponadto do wyjątków należały państwa, w których parlamenty informowane były przez rządy o dalszym biegu działań prawotwórczych, na podstawie przedstawionych projektów. Choć utrwaliła się praktyka rozpatrywania przez parlamenty propozycji legislacyjnych Komisji, to jedynie w niektórych przypadkach istniała możliwość opóźnienia przyjęcia propozycji Komisji ze względu na okoliczność rozpatrywania ich przez krajowe organy parlamentarne. Niekiedy realizację utrudniała sama Komisja Europejska, gdyż przekazywała propozycje rządom tak późno, że ich dogłębna analiza w parlamencie narodowym nie była możliwa ${ }^{21}$.

Zarysowana w traktacie z Maastricht tendencja do umocnienia roli parlamentów narodowych w procesach decyzyjnych UE utrwalona została w wyniku postanowień Traktatu z Amsterdamu (1997). Na mocy tego Traktatu dołączony został do Traktatu o Unii Europejskiej i traktatów ustanawiających Wspólnoty Protokót $w$ sprawie roli parlamentów narodowych w Unii Europejskiej ${ }^{22}$. Uściślono w nim warunki pozwalające parlamentom narodowym na monitorowanie procesu legislacyjnego na szczeblu wspólnotowym ${ }^{23}$. Komisję Europejską zobowiązano do niezwłocznego przekazywania parlamentom narodowym takich dokumentów, jak zielone księgi, białe księgi i komunikaty, choć pominięto dokumenty dotyczące wspólnej polityki zagranicznej i bezpieczeństwa. Ustalono też, że projekty legislacyjne Komisji Europejskiej muszą być przekazywane rządom

${ }^{21}$ Zob. E. Popławska, Organy i procedura stanowienia prawa wspólnotowego oraz udziat w niej państw członkowskich, [w:] Prawo międzynarodowe i wspólnotowe w wewnętrznym porządku prawnym, Wydawnictwo Sejmowe, Warszawa 1997, s. 182-183.

22 Polski tekst: Dz.U. z 2004 r. Nr 90, poz. 864. Por. Z. Brodecki, M. Drobysz, S. Majkowska, D. Pyć, M. Tomaszewska, I. Żużewicz, Traktat o Unii Europejskiej. Traktat ustanawiający Wspólnotę Europejską. Komentarz, red. Z. Brodecki, wyd. 2, LexisNexis, Warszawa 2006, s. 13.

${ }^{23}$ Zob. A. Maurer, Parlamenty narodowe po Amsterdamie: adaptacja, dostosowanie skali oraz sukcesywna realizacja, [w:] Rola parlamentów narodowych w perspektywie rozszerzenia UE oraz Konferencji Międzyrzqdowej 2004, Warszawa 2002, s. 210. 
tych państw z takim wyprzedzeniem, aby parlamenty miały odpowiedni czas na zapoznanie się z nimi. Postanowiono też, że w odniesieniu do propozycji środków i projektów aktów prawnych objętych III filarem UE (współpraca sądowa i policyjna w sprawach karnych) pomiędzy zgłoszeniem projektu we wszystkich językach urzędowych do Rady UE i Parlamentu Europejskiego, a wpisaniem go do porządku obrad Rady w celu podjęcia decyzji uchwalenia aktu prawnego lub przyjęcia wspólnotowego stanowiska musi upłynąć co najmniej sześć tygodni. Jest to ważne z punktu widzenia możliwości zapoznania się z tymi aktami przez parlamenty krajowe ${ }^{24}$.

W Deklaracji nr 23 o przyszłości Unii Europejskiej, dołączonej do Traktatu z Nicei (2001) kwestię roli parlamentów narodowych uznano za jedną z najpilniejszych do rozwiązania. Parlament Europejski sygnalizował w tym kontekście, że ,deficyt demokracji” w UE może się zaostrzyć z powodu braku postępu w sferze ,demokratycznego monitorowania procesów demokratycznych” ${ }^{25}$.

Istotne znaczenie dla poszukiwania miejsca parlamentów narodowych we wspólnotowym procesie decyzyjnym miały prace Konwentu Europejskiego ${ }^{26}$ i przygotowany przezeń Traktat Ustanawiający Konstytucję dla Europy ${ }^{27}$. Zaproponowano w nim, by parlamenty narodowe otrzymały prawo do informacji, równocześnie z ustawodawcą unijnym, o projektach aktów, ich zmianie oraz uchwałach legislacyjnych Parlamentu Europejskiego i stanowiskach Rady Ministrów ${ }^{28}$. Parlamenty narodowe mogłyby też przesyłać Parlamentowi Europejskiemu, Radzie Ministrów i Komisji uzasadnioną opinię na temat sprzeczności z zasadą pomocniczości. Komisja musiałaby wówczas ponownie rozpatrzyć swój projekt w przypadku, gdy parlamenty narodowe wypowiedziałyby się co najmniej jedną trzecią głosów za istnieniem sprzeczności (w przypadku Przestrzeni Wolności,

${ }^{24}$ Zob. E. Popławska, Formy wspótpracy parlamentów w Unii Europejskiej, [w:] Parlamenty a integracja europejska, red. M. Kruk, E. Popławska, Wydawnictwo Sejmowe, Warszawa 2002, s. 210.

25 J. Marszałek-Kawa, Parlament Europejski a parlamenty narodowe w Unii Europejskiej, Wydawnictwo MADO, Toruń 2005, s. 358.

${ }^{26}$ Zob. J. Trzciński, Rola Parlamentu Europejskiego i parlamentów narodowych w projekcie Traktatu Konstytucyjnego. Tezy wykładu, [w:] Parlament Europejski i parlamenty narodowe, red. B. Banaszak, Wydawnictwo Uniwersytetu Wrocławskiego, Wrocław 2004, s. 11; M. Borowski, Rola parlamentów narodowych w projekcie Traktatu ustanawiającego Konstytucję dla Europy, „Przegląd Sejmowy” 2003, nr 5, s. 9.

27 Zob. S. Martinelli, Le rôle des parlements nationaux dans l'architecture européenne, «Revue du droit de l'Union européenne» 2004, nr 4, s. 756.

${ }^{28}$ Por. P. Kiiver, The Composite Case for National Parliaments in the European Union: Who Profits from Enhanced Involvement?, "European Constitutional Law Review" 2006, nr 2, s. 231. 
Bezpieczeństwa i Sprawiedliwości wystarczyłaby jedna czwarta głosów ${ }^{29}$. Z tym „,systemem wczesnego ostrzegania” wiązano nadzieje na ograniczenie „deficytu demokracji”" 30 .

Traktat Ustanawiający Konstytucję dla Europy (2004) nie wszedł jednak w życie. Po odrzuceniu go w referendach we Francji i w Holandii, a także wyrażeniu sceptycyzmu w innych państwach (m.in. w Polsce i w Wielkiej Brytanii) ${ }^{31}$ odstąpiono od kontynuacji jego procedury ratyfikacyjnej, a w miejsce tego zdecydowano się na pracę nad formułą mniej ambitną w postaci Traktatu reformującego. Został on podpisany w dniu 13 grudnia 2007 r. w Lizbonie ${ }^{32}$. Uwzględnił on jednak kluczowe propozycje rozwiązań dotyczących roli parlamentów narodowych, jakie były uwzględnione w Traktacie konstytucyjnym ${ }^{33}$.

\section{POSTANOWIENIA TRAKTATU Z LIZBONY W KWESTII ROLI PARLAMENTÓW NARODOWYCH}

Traktat z Lizbony ${ }^{34}$ oznacza niewątpliwie, $w$ interesującym tu nas aspekcie, kolejną próbą umocnienia roli parlamentów narodowych we wspólnotowych procesach decyzyjnych ${ }^{35}$. Nowy art. 12 Traktatu o Unii Europejskiej w brzmieniu nadanym Traktatem z Lizbony głosi, że „Parlamenty narodowe aktywnie przyczyniają się do prawidłowego funkcjonowania Unii” i wymienia środki w dyspozycji

29 Zob. M. Górka, Udziat Parlamentu Europejskiego i parlamentów narodowych w procedurach legislacyjnych w Unii Europejskiej, ,Przegląd Sejmowy” 2004, nr 2, s. 92

30 Zob. J. Cooper, The Watchdogs of Subsidiarity: National Parliaments and the Logic of Arguing in the EU, "Journal of Common Market Studies" 2006, nr 2, s. 299.

31 Zob. J. Barcz, Możliwość reformy ustrojowej UE w warunkach odrzucenia Traktatu konstytucyjnego, [w:] Prezydencja niemiecka a stan debaty o reformie Unii Europejskiej. Aspekty polityczno-prawne, red. J. Barcz, Wydawnictwo Wyższej Szkoły Przedsiębiorczości i Zarządzania, Warszawa 2007, s. 84.

32 Zob. J. Jaskiernia, Rola parlamentów narodowych w Unii Europejskiej w świetle Traktatu z Lizbony, [w:] Księga pamiq̨tkowa profesora Marcina Kudeja, red. A. Łabno, E. Zwierzchowski, Oficyna Wydawnicza Wacław Walasek, Katowice 2009, s. 224 i nast.

${ }^{33}$ Zob. G. Barrett, „The King is Dead, Long Live the King”: the Recasting Treaty of Lisbon of the Provisions of the Constitutional Treaty Concerning National Parliaments, "European Law Review" 2008, nr 1, s. 68.

34 Traktat z Lizbony zmieniający Traktat o Unii Europejskiej i Traktat ustanawiający Wspólnotę Europejską podpisany w Lizbonie dnia 13 grudnia 2007 r., Dz. Urz. UE, 17 grudnia 2007, t. 50, C 306.

35 Por. R. Corbett, The Evolving Roles of the European Parliament and of National Parliaments, [w:] EU Law after Lisbon, red. A. Biondi, P. Eeckhout, S. Ripley, Oxford University Press, Oxford 2012. 
parlamentów, w zakresie czuwania nad zasadami pomocniczości i proporcjonalności, odsyłając do protokołu w sprawie stosowania tych zasad. Jeśli wcześniej narodowe legislatywy uczestniczyły w procesach decyzyjnych związanych z nabyciem i realizacją praw członkowskich w Unii w zakresie i na zasadach określonych przez każde z państw oddzielnie, zgodnie z ich modelem ustrojowym i regulacjami konstytucyjnymi, to Traktat z Lizbony po raz pierwszy przypisał expressis verbis parlamentom narodowym, a nawet ich poszczególnym izbom, prawo wpływania na istotne rozstrzygnięcia w UE. Państwa-sygnatariusze Traktatu z Lizbony zostały w ten sposób zobligowane do takiej regulacji funkcjonowania parlamentów w ustawach zasadniczych i aktach podkonstytucyjnych oraz do wprowadzenia odpowiednich praktyk (np. w Wielkiej Brytanii, gdzie nie ma konstytucji w sensie formalnym), które umożliwiają korzystanie z tych uprawnień. UE przede wszystkim nadaje bądź rozwija, w porównaniu z poprzednim stanem prawnym, możliwości oddziaływania parlamentów narodowych na decyzje na szczeblu europejskim, ani nie nakładając na nie konkretnych zobowiązań (powstrzymanie się od działania przez parlament lub jego izbę nie stanowi przeszkody w przyjęciu danego rozstrzygnięcia unijnego), ani nie przesądzając formy, w jakich parlamenty miałyby z nich korzystać. Zarówno w świetle traktatów, jak i protokołów, funkcje parlamentów narodowych w sprawach europejskich są co do zasady określone ramowo, natomiast do prawa krajowego należy nadanie im ostatecznego kształtu organizacyjnego ${ }^{36}$.

Kwestie te zostały uwzględnione m.in. w Protokole $w$ sprawie roli parlamentów narodowych w Unii Europejskiej, będącego jednym z protokołów do dołączenia do Traktatu o Unii Europejskiej, Traktatu o funkcjonowaniu Unii Europejskiej i, w stosownym przypadku, do Traktatu ustanawiającego Europejską Wspólnotę Energii Atomowej ${ }^{37}$.

W preambule Protokołu przypomniano, że „sposób, w jaki parlamenty narodowe sprawują kontrolę nad swoimi rządami w odniesieniu do działań Unii Europejskiej należy do organizacji i praktyki konstytucyjnej każdego Państwa Członkowskiego". Nie nastąpiło więc w tym zakresie ograniczenie suwerenności na rzecz UE.

Motywacja przyjęcia Protokołu wiązała się z tym, że pragnięto ,zachęcić parlamenty narodowe do bardziej aktywnego udziału w działaniach Unii Europejskiej i zwiększyć możliwość wyrażenia przez nie ich punktu widzenia w sprawie

${ }^{36}$ Zob. E. Popławska, Rola parlamentów narodowych w świetle Traktatu z Lizbony, „Przegląd Sejmowy" 2010, nr 5, s. 157-158.

37 Dz. Urz. UE, 17 grudnia 2007, C 306/148. 
projektów aktów prawodawczych Unii Europejskiej, a także w innych kwestiach, które mogą stanowić dla nich przedmiot szczególnego zainteresowania".

Zasadnicza kwestia uwzględniona w Protokole dotyczy informacji dla parlamentów narodowych. Jest więc kontynuacją tych poszukiwań, które zapoczątkowano w protokołach dołączonych do traktatów z Maastricht i Amsterdamu. Postanowiono, że „dokumenty konsultacyjne Komisji (zielone księgi, białe księgi i komunikaty) są przekazywane, po ich opublikowaniu, parlamentom narodowym bezpośrednio przez Komisję. Komisja przekazuje również parlamentom narodowym roczny program prac legislacyjnych oraz wszelkie inne dokumenty dotyczące planowania legislacyjnego lub strategii politycznej równocześnie z ich przekazaniem Parlamentowi Europejskiemu i Radzie" (art. 1).

Jednoznacznie też przesądzono w art. 2, że ,projekty aktów ustawodawczych (w oryginalnym dokumencie słowo to tłumaczone było jako ,akty prawodawcze” - przyp. J.J.) kierowane do Parlamentu Europejskiego i do Rady są przekazywane parlamentom narodowym”, przy czym przez ,,projekty aktów ustawodawczych” rozumie się w Protokole: wnioski Komisji, inicjatywy grupy Państw Członkowskich, inicjatywy Parlamentu Europejskiego, wnioski Trybunału Sprawiedliwości, zalecenia Europejskiego Banku Centralnego i wnioski Europejskiego Banku Inwestycyjnego mające na celu przyjęcie aktu ustawodawczego. Również ,projekty aktów ustawodawczych pochodzące od Komisji są przekazywane parlamentom narodowym bezpośrednio przez Komisję równocześnie z ich przekazaniem Parlamentowi Europejskiemu i Radzie". Podobnie rzecz się ma z projektami aktów ustawodawczych pochodzących od Parlamentu Europejskiego, które przekazywane są parlamentom narodowym bezpośrednio przez Parlament Europejski. Natomiast w odniesieniu do aktów ustawodawczych pochodzących od Państw Członkowskich, Trybunału Sprawiedliwości, Europejskiego Banku Centralnego lub Europejskiego Banku Inwestycyjnego obowiązuje zasada, że przekazywane są parlamentom narodowym przez Radę.

Można więc stwierdzić, że w kwestii przekazywania projektów aktów ustawodawczych obowiązuje zasada, że przekazywane są one parlamentom narodowym bezpośrednio przez ich autorów, a tylko w odniesieniu do niektórych kategorii obowiązuje pośrednictwo Rady. Najistotniejsze jest wszakże to, że bezpośrednim adresatem jest tu parlament narodowy, a nie jest przewidziane pośrednictwo rządu narodowego. W ten sposób wyeksponowana jest podmiotowość parlamentów narodowych we wspólnotowych procesach decyzyjnych.

Parlamenty narodowe mogą przesyłać, jak stanowi art. 3 Protokołu, przewodniczącemu Parlamentu Europejskiego, Rady i Komisji ,uzasadnioną opinię na temat zgodności projektu aktu ustawodawczego z zasadą pomocniczości, zgodnie 
z procedurą przewidzianą w Protokole $w$ sprawie stosowania zasad pomocniczości i proporcjonalności”. Jeśli projekt aktu pochodzi od grupy Państw Członkowskich, ,,przewodniczący Rady przekazuje uzasadnione opinię lub opinie rządom tych Państw Członkowskich". Jeśli natomiast projekt aktu ustawodawczego pochodzi od Trybunału Sprawiedliwości, Europejskiego Banku Centralnego lub Europejskiego Banku Inwestycyjnego, ,przewodniczący Rady przekazuje uzasadnione opinię lub opinie danej instytucji lub organowi”.

$\mathrm{Na}$ analizę zasługuje tu pojęcie „uzasadnionej opinii”, jakim posługuje się polskie tłumaczenie Protokołu. Chodzi tu, jak się wydaje, nie o to, że opinia ma być uzasadniona, co kładłoby punkt ciężkości na jej zawartość (bo wtedy rodziłoby się pytanie: czyje zdanie ma tu przesądzać o jej ,zasadności”), a to, że ma ona zawierać uzasadnienie, które wyjaśnia jej motywacje.

$\mathrm{W}$ art. 4 Protokołu przesądzono, że termin między przekazaniem parlamentom narodowym projektu aktu ustawodawczego w językach urzędowych Unii a datą jego wstępnego wpisania do porządku obrad Rady w celu jego przyjęcia lub przyjęcia stanowiska $w$ ramach procedury prawodawczej wynosi osiem tygodni. W pilnych przypadkach możliwe są jednak wyjątki, które zostają uzasadnione w akcie lub stanowisku Rady. Z wyjątkiem przypadków pilnych, które zostały należycie uzasadnione, w ciągu tych ośmiu tygodni nie zawiera się żadnego porozumienia w sprawie projektu aktu ustawodawczego. Ponadto, z wyjątkiem przypadków pilnych, które zostały należycie uzasadnione, termin między wpisaniem projektu aktu ustawodawczego do wstępnego porządku obrad Rady a przyjęciem stanowiska wynosi dziesięć dni.

Niewątpliwie konstrukcja ta ma na celu zapewnienie odpowiedniego czasu, by parlamenty narodowe mogły przeprowadzić skutecznie proces opiniodawczy. Uwzględniać on musi czas na ewentualne zasięgnięcie opinii ekspertów i przygotowanie przez nich uwag, które mogłyby być wykorzystane w procedurze parlamentarnej. Instytucja trybu pilnego nie wzbudza tu wątpliwości, bo znana jest także z procedur w parlamentach narodowych. Na krytykę zasługuje natomiast to, że nie przewidziano żadnych reguł dla takich pilnych przypadków. Jeśli bowiem można uznać, że termin ośmiotygodniowy jest w takich przypadkach zbyt długi, to powinny być jednak określone pewne minimalne granice. W aktualnym stanie Rada nie jest, w sytuacji przypadku pilnego, związana żadnymi regułami. Klauzula, że chodzi o przypadki, które ,zostały należycie uzasadnione” nie może tu być uznana za wystarczającą, bo nie określono procedury, w ramach której parlamenty narodowe mogłyby zakwestionować takie uzasadnienie. Na pełną ocenę skutków tej konstrukcji trzeba będzie jednak poczekać. To dopiero bowiem praktyka jej stosowania pokaże, czy chodzi tu o rzeczywiście sytuacje wyjątkowe, 
czego nie sposób kwestionować, czy też jest to furtka, przez którą dochodzi do zasadniczego podważenia tej formuły o istotnym znaczeniu gwarancyjnym dla parlamentów narodowych.

Uprawnienie to odnoszone jest do ,unijnych aktów ustawodawczych, a więc nie do wszystkich unijnych aktów prawnych, jak również do przesyłania uzasadnionej opinii w odniesieniu do tej kategorii aktów prawnych"38. Precyzyjne zdefiniowanie zakresu pojęcia aktów ustawodawczych ma kluczowe znaczenie dla określenia rzeczywistego zakresu przedmiotowego kompetencji parlamentów narodowych do badania przestrzegania zasady pomocniczości. Podczas posiedzenia przewodniczących Konferencji Organów Parlamentarnych Wyspecjalizowanych w Sprawach Unii (COSAC) delegacja Izby Gmin Wielkiej Brytanii poruszyła problem niejasności co do pojęcia ,aktów ustawodawczych” w świetle postanowień Traktatu z Lizbony. W szczególności wątpliwości budzi zakres pojęcia aktów ustawodawczych w odniesieniu do aktów przyjmowanych w specjalnej procedurze ustawodawczej, która nie została wprost zdefiniowana w traktatach ustanawiających Unie Europejską ${ }^{39}$.

Akty ustawodawcze zostały zdefiniowane w art. 289 ust. 3 Traktatu o funkcjonowaniu Unii Europejskiej (TFUE) jako akty przyjmowane w procedurze ustawodawczej. Uwzględniając postanowienia art. 289 ust. 1 i 2 TFUE, są to akty przyjmowane $\mathrm{w}$ zwyklej lub specjalnej procedurze ustawodawczej. W podobny sposób został zdefiniowany akt ustawodawczy w art. 3 Protokołu $w$ sprawie stosowania zasad pomocniczości i proporcjonalności, którzy stanowi, że przez projekty aktów ustawodawczych rozumie się wnioski i inicjatywy instytucji UE lub grupy państw członkowskich „mające na celu przyjęcie aktu ustawodawczego”. Od aktów ustawodawczych należy odróżnić akty delegowane oraz akty wykonawcze, a także niektóre kategorie aktów „bezprzymiotnikowych”. Akty delegowane, zdefiniowane w art. 290 TFUE, są przyjmowane wyłącznie przez Komisję. Akty te mogą zmieniać lub uzupełniać inne niż istotne elementy aktu ustawodawczego. Natomiast akty wykonawcze mogą być, zgodnie z art. 291 TFUE, przyjmowane przez Komisję lub Radę w celu ustanowienia jednolitych warunków wykonania nie tylko aktu ustawodawczego, ale wszystkich prawnie wiążących aktów Unii. O tym, czy konkretny akt prawny UE stanowi akt ustawodawczy, decyduje przede wszystkim podstawa prawna jego wydania. Jeśli znajduje się ona w akcie ustawodawczym lub innym akcie prawa wtórnego (np. decyzji przyjętej w ramach

${ }^{38}$ M Słok-Wódkowska, Zakres przedmiotowy kompetencji parlamentów narodowych do badania zasady pomocniczości w świetle Traktatu z Lizbony, „Przegląd Sejmowy” 2010, nr 4, s. 141.

39 Tamże. 
wspólnej polityki zagranicznej i bezpieczeństwa), to nie ulega wątpliwości, że taki akt nie jest aktem ustawodawczym. Znacznie trudniejsze jest natomiast rozstrzygnięcie, czy akt przyjmowany bezpośrednio na podstawie przepisów traktatowych stanowi akt ustawodawczy. Zgodnie z art. 31 ust. 1 Traktatu o Unii Europejskiej (TUE) wyklucza się stosowanie aktów ustawodawczych przy przyjmowaniu decyzji w ramach Wspólnej Polityki Zagranicznej i Bezpieczeństwa. W tej dziedzinie przyjmowane są zatem akty „,bezprzymiotnikowe” oraz wykonawcze. W pozostałych dziedzinach do określenia, czy dany akt jest aktem ustawodawczym, rozstrzygająca jest treść delegacji do jego wydania zawarta w traktacie. Definicja aktu ustawodawczego zawarta w art. 289 TFUE zakłada, że taki akt musi być przyjmowany we współpracy Rady i Parlamentu Europejskiego. Jeśli więc TUE albo TFUE przewidują, że organem właściwym do wydania aktu jest Rada samodzielnie, to taki akt będzie aktem „,bezprzymiotnikowym”"40.

Tak więc w myśl tej interpretacji badaniu przestrzegania zasady pomocniczości podlegają wszystkie akty ustawodawcze, zarówno przyjęte w zwykłej, jak i specjalnej procedurze ustawodawczej. Protokół nr 2 wyłącza natomiast taką możliwość w odniesieniu do innych aktów prawnych. Brak jednak procedury kontroli ex ante przestrzegania zasady pomocniczości nie wyklucza stosowania tej zasady w stosunku do innych działań. Natomiast pewne wątpliwości budzi zakwalifikowanie aktów prawnych w stosunku do których w podstawie prawnej nie wskazano wyraźnie, iż są przyjmowane w specjalnej procedurze prawodawczej, mimo że faktyczna procedura polega na konsultacji z PE lub zgodzie PE. Tego rodzaju akty nie należą jednak do aktów ustawodawczych. Pomimo więc pewnych wątpliwości związanych z art. 352 ust. 1 TFUE uznaje się, że akty, w stosunku do których nie wskazano, że są przyjmowane w specjalnej procedurze bądź w zwykłej procedurze ustawodawczej, nie stanowią aktów ustawodawczych. W tej sytuacji parlamentom narodowym nie przysługuje w stosunku do tego rodzaju aktów prawnych uprawnienie do kontroli zgodnie z zasada pomocniczości ${ }^{41}$.

Racjonalnym uzupełnieniem powyższych reguł jest to, że porządki obrad i wyniki posiedzeń Rady, w tym protokoły posiedzeń Rady rozpatrującej projekty aktów ustawodawczych, są przekazywane bezpośrednio parlamentom narodowym, równocześnie z ich przekazaniem rządom Państw Członkowskich (art.

40 Tamże, s. 144-145. Por. C. Herma, Reforma systemu aktów prawa pochodnego $w$ UE w Traktacie z Lizbony, „Europejski Przegląd Sądowy” 2008, nr 5, s. 22 i nast.; tegoż, Nowy system aktów prawa pochodnego Unii Europejskiej. Postanowienia Traktatu z Lizbony i ich geneza, [w:] Quo vadis Europo III, red. E. Piontek, K. Karasiewicz, Urząd Komitetu Integracji Europejskiej, Warszawa 2009, s. 192 i nast.

${ }^{41}$ Zob. E. Słok-Wódkowska, Zakres..., s. 151-152. 
5). Jeśli natomiast Rada Europejska, jak stanowi art. 6, zamierza powołać się na art. 48 ust. 7 akapit pierwszy lub drugi Traktatu o Unii Europejskiej, parlamenty narodowe są informowane o tej inicjatywie Rady Europejskiej co najmniej na sześć miesięcy przed przyjęciem jakiejkolwiek decyzji. Uzupełnieniem tych dyspozycji jest postanowienie art. 7, w myśl którego Trybunał Obrachunkowy przekazuje swoje sprawozdanie roczne parlamentom narodowym w celach informacyjnych, równocześnie z przekazaniem go Parlamentowi Europejskiemu i Radzie.

Najistotniejsze znaczenie ma, przewidziane w Protokole $w$ sprawie stosowania zasad pomocniczości i proporcjonalności $i^{42}$, uprawnienie parlamentu narodowego lub każdej izby parlamentu narodowego, by w terminie ośmiu tygodni od daty przekazania projektu w językach urzędowych Unii, jak stanowi art. 6, ,przesłać przewodniczącym Parlamentu Europejskiego, Rady i Komisji uzasadnioną opinię zawierającą powody, dla których uznaje, że dany projekt nie jest zgodny z zasadą pomocniczości”. Do parlamentu narodowego lub izby parlamentu narodowego należy przy tym konsultowanie się, w stosownym przypadku, z parlamentami regionalnymi mającymi kompetencje prawodawcze.

W przypadku, gdy takie opinie o niezgodności stanowią co najmniej jedną trzecią głosów przyznanych parlamentom narodowym, projekt zostaje poddany ponownej analizie (art. 7 ust. 1). Próg ten jest niższy i wynosi jedną czwartą w przypadku dotyczącym przestrzeni wolności, bezpieczeństwa i sprawiedliwości (art. 7 ust. 2).

Ostatecznie więc „system wczesnego ostrzegania”, przewidziany oryginalnie w Traktacie Konstytucyjnym, ale nie wdrożony wówczas w życie, uzyskał szansę na realizację, w znaczący sposób wzmacniając pozycję parlamentów narodowych we wspólnotowych procesach prawotwórczych. Niektórzy sugerują, że „system wczesnego ostrzegania" (Early Warning System - EWS) może być przyrównany do roli, jaką w niektórych systemach politycznych odgrywają rady państwa, których opinie nie mają wiążącego charakteru, ale podlegają zinstytucjonalizowanym procedurom, ponadto zorientowane są na badanie zgodności prawem (w tym wypadku z zasada pomocniczości), a nie na rozważaniu merytorycznej zasadności ${ }^{43}$.

Postanowienia protokołów dołączonych do Traktatu z Lizbony, dotyczących roli parlamentów narodowych w Unii Europejskiej, jak też w sprawie stosowania zasad pomocniczości i proporcjonalności wskazują, że mimo niepowodze-

42 Dz. Urz. UE, 17 grudnia 2007, C 306/150.

${ }^{43}$ Zob. P. Kiiver, The Early-Warning System for the Principle of Subsidiarity: the National Parliament as a Conseil d'État for Europe, "European Law Review” 2011, nr 1, s. 101. 
nia próby ratyfikacji Traktatu ustanawiającego Konstytucję dla Europy, udało się ochronić te postanowienia, które wiążą się z umocnieniem parlamentów narodowych we wspólnotowym procesie decyzyjnym. Nie potwierdziły się więc obawy, że odrzucenie Traktatu Konstytucyjnego nie stworzy szansy na umocnienie roli Parlamentu Europejskiego ( $w$ wyniku poszerzenia zasięgu procedury ko-decyzyjnej), a także na zwiększenie znaczenia parlamentów narodowych, zwłaszcza w procesie kontroli zgodności aktów prawnych z zasadą pomocniczości ${ }^{44}$. Wartości te uwzględnione zostały bowiem w Traktacie z Lizbony. Z drugiej jednak strony wskazuje się, że zjawisko „deparlamentaryzacji” ograniczone zostało przez ten Traktat tylko w ograniczonym zakresie. Uprawnienia zawarte w cytowanych protokołach zwiększyły bowiem co prawda horyzontalny dialog pomiędzy parlamentami w ramach monitoringu zasady subsydiarności, ale nie zwiększyły legitymizacji procesu ustawodawczego ${ }^{45}$.

Nie sposób jednak nie zauważyć, ze Traktat z Lizbony przyniósł jednak nowe możliwości dla parlamentów narodowych. Niektórzy nawet sugerują, że urosły one do roli „,wirtualnej trzeciej izby” (obok Parlamentu Europejskiego i Rady), posiadającej trzy kluczowe funkcje parlamentarne: ustawodawczą, reprezentacyjną i deliberacyjną. Parlamenty narodowe uzyskały bowiem zinstytucjonalizowany wpływ na procesu ustawodawcze w Unii. Powstał w konsekwencji nowy kanał łączący obywateli z Unią. Powstało też nowe forum debatowania propozycji ustawodawczych pod kątem zgodności z zasadą pomocniczości ${ }^{46}$. Dzięki temu obywatele państw członkowskich znajdą się bliżej spraw istotnych dla całej Unii, a obserwowana dzisiaj „opozycyjność” legislatur narodowych wobec niej, jako „instytucji, która zabrała nam kompetencje”, osłabnie ${ }^{47}$.

$\mathrm{Na}$ kwestię tę można spojrzeć także przez pryzmat zachwiania równowagi władz i deparlamentaryzacji ustrojów państw członkowskich. Proces ten w istotny sposób dotyka legislatywy krajowe, które tracąc możliwość swobodnego stanowienia prawa w dziedzinach należących do zakresu działania Unii Europejskiej,

${ }^{44}$ Zob. H.F. Köck, European Parliament and National Parliaments in the Draft Constitution for Europe, [w:] Parlament Europejski i parlamenty narodowe, red. B. Banaszak, Wydawnictwo Uniwersytetu Wrocławskiego, Wrocław 2004, s. 38.

45 Zob. A. Cygan, The Parliamentarisation of EU Decision-Making?: The Impact of Lisbon on National Parliaments, "European Law Review” 2011, nr 4, s. 482.

46 Zob. I. Coopper, A „Virtual Thir Chamber” for the European Union?: National Parliaments after the Treaty of Lisbon, "West European Politics" 2012, nr 3, s. 445.

47 Zob. R. Balicki, Parlament narodowy w systemie decyzyjnym Unii Europejskiej (po wejściu $w$ życie Traktatu z Lizbony), [w:] Instytucje prawa konstytucyjnego w dobie integracji europejskiej. Księga jubileuszowa dedykowana prof. Marii Kruk-Jarosz, red. J. Wawrzyniak, M. Laskowska, Wydawnictwo Sejmowe, Warszawa 2009, s. 342-343. 
osłabiają swe dotychczasowe znaczenie ${ }^{48}$.Ta tendencja prowadzi do tego, że jak sugeruje Krzysztof Wojtyczek - ,władza ustawodawcza jest wykonywana przez rządy państw członkowskich reprezentowane przez swoich przedstawicieli w Radzie, a parlamenty krajowe przekształcają się stopniowo w organy w władzy wykonawczej, wydając akty prawodawcze (w formie ustawy) niezbędne do implementowania i wykonywania prawa UE"49. Należy wszakże odnotować, że ta tendencja dotyczy jedynie części kompetencji ustawodawczych, które zostały przekazane do kompetencji Unii. W pozostałym zakresie parlament narodowy nie przestaje być organem władzy ustawodawczej, choć zakres realizacji tej funkcji ulega zasadniczej modyfikacji ${ }^{50}$.

Traktat z Lizbony przewiduje także powierzenie parlamentom narodowym pewnych kompetencji kontrolnych wobec Unii. Postanowienia traktatowe nie są tu jednak zbyt precyzyjne i mogą rodzić wątpliwości. W myśl art. 12 pkt c TUE parlamenty narodowe uczestniczą, w ramach przestrzeni wolności, bezpieczeństwa i sprawiedliwości ${ }^{51}$, w mechanizmach oceniających wykonanie polityk Unii w tej dziedzinie, zgodnie z art. 70 TFUE oraz włączają się w polityczną kontrolę Europolu i ocenę działalności Eurojustu, zgodnie z art. 85 i 88 tego Traktatu. Zwraca się w związku z tym uwagę, że art. 70 TFUE stanowi: „Rada, na wniosek Komisji, może przyjąć środki ustanawiające warunki dokonywania przez Państwa Członkowskie, we współpracy z Komisją, obiektywnej i bezstronnej oceny wprowadzenia w życie przez władze Państw Członkowskich polityk Unii, o których mowa w niniejszym tytule, w szczególności w celu sprzyjania pełnemu stosowaniu zasady wzajemnego uznawania. Parlament Europejski oraz parlamenty narodowe są informowane o treści i wynikach tej oceny". Udział parlamentów narodowych w mechanizmach oceniających wykonanie polityk Unii sprowadzałby się w tym przypadku do otrzymywania informacji. Zgodnie z art. 85 i art. 88 TFUE zasady udziału parlamentów krajowych w ocenie Eurojustu i kontroli Europolu miałyby określać rozporządzenia unijne. Na gruncie samego Traktatu nie jest

48 Zob. R. Grzeszczak, Parlamenty państw członkowskich w Unii Europejskiej, Wydawnictwo Uniwersytetu Wrocławskiego, Wrocław 2004, s. 237; J. Jaskiernia, Parlament i procesy integracyjne, [w:] Parlament. Model konstytucyjny a praktyka ustrojowa, red. Z. Jarosz, Wydawnictwo Sejmowe, Warszawa 2006, s. 177.

${ }^{49}$ K. Wojtyczek, Wptyw Traktatu z Lizbony na ustrój Polski, „Przegląd Sejmowy” 2010, nr 4, s. 35 .

${ }^{50}$ Zob. J. Jaskiernia, Wptyw integracji z Unia Europejska na funkcję ustawodawczq Sejmu RP, „Studia Prawnicze” 2006, nr 3, s. 33.

51 Zob. J. Jaskiernia, Unia Europejska jako Przestrzeń Wolności, Bezpieczeństwa i Sprawiedliwości (model normatywny w świetle Traktatu z Lizbony), „Bezpieczeństwo i Ochrona” 2008, nr 3-4, s. 13. 
jednak jasne, jakie konkretne kompetencje kontrolne uzyskały parlamenty narodowe. Zagadnienie to musi być więc sprecyzowane w prawie pochodnym. Po wydaniu odpowiednich aktów prawa unijnego regulujących kompetencje kontrolne parlamentów narodowych, niezbędne mogą się okazać zmiany regulaminów parlamentarnych, a nawet przepisów konstytucyjnych. Traktat z Lizbony nadaje bowiem funkcji kontrolnej parlamentów nowy, europejski wymiar ${ }^{52}$.

Ponadto parlamenty narodowe uzyskały kompetencję do uczestnictwa w procedurach zmiany Traktatu o Unii Europejskiej i Traktatu o funkcjonowaniu Unii Europejskiej (notyfikacja propozycji zmiany traktatów oraz udział przedstawicieli parlamentów narodowych w konwencie w zwykłej procedurze aminy art. 48 ust. 2 i swoiste prawo weta $\mathrm{w}$ przypadku uproszczonego trybu zmiany $\mathrm{z}$ art. 48 ust. 7), a także do informowania o wnioskach o przystąpienie do Unii (art. 49 TUE). Parlamenty narodowe uzyskały także, na mocy Traktatu z Lizbony, prawo do bycia informowanymi o wnioskach państw europejskich, podzielających aksjologię Unii Europejskiej, o członkostwo. Wskazuje się, że nowe uprawnienia parlamentów narodowych powinny być poszerzone co najmniej o prawo do ustosunkowania się do przedstawienia państwu członkowskiemu zarzutu poważnego narażenia wartości unijnych i ewentualnego zastosowania przewidzianych sankcji. Byłby to bowiem logiczny korelat ich roli przy przyjmowaniu nowych członków. Logicznym byłoby też uwzględnienie informowania parlamentów o zgłoszonym przez państwo zamiarze wystąpienia z Unii, skoro wiązałoby się ono z renegocjacja traktatów ${ }^{53}$.

Niewątpliwie Traktat z Lizbony, wzmacniając pozycję parlamentów narodowych, a także poszerzając kompetencje Parlamentu Europejskiego, oznacza krok w kierunku zmniejszenia „deficytu demokracji” w Unii Europejskiej, ale z pewnością nie doprowadzi do pełnego wyeliminowania tego zjawiska. Wynika ono z samej konstrukcji reprezentowania państw we wspólnotowych procesach decyzyjnych przez rządy ${ }^{54}$. Tak długo, jak ten model będzie obowiązywał, tak długo nie sposób wyeliminować „deficytu demokracji”, a można działać jedynie na rzecz jego ograniczenia, poszerzając pola aktywności parlamentów narodowych i Parlamentu Europejskiego, a także szukając innych sposobów wyrażania stanowiska przez europejską opinię publiczną we wspólnotowych procesach

52 Zob. K. Wojtyczek, Wptyw..., s. 36.

53 Zob. E. Popławska, Rola ..., s. 167-168.

54 Zob. J. Jaskiernia, Kompetencja rzqdu do reprezentowania państwa we wspólnotowych procesach decyzyjnych a problem „deficytu demokracji” w Unii Europejskiej, [w:] Ustroje, doktryny, instytucje polityczne. Ksiegga jubileuszowa Profesora zw. dra hab. Mariana Grzybowskiego, red. J. Czajowski (i in.), Wydawnictwo Uniwersytetu Jagiellońskiego, Kraków 2007, s. 134. 
decyzyjnych. Niewątpliwie więc rację ma Adam Cygan, gdy pisze, w nawiązaniu do postanowień Traktatu z Lizbony, o sytuacji parlamentów narodowych w systemie decyzyjnym Unii Europejskiej: „,nie są już przegranymi, ale nie sposób ich określić zwycięzcami”"55.

Traktat z Lizbony nie stanowi więc jakiegoś zasadniczego przełomu w zakresie procesu decyzyjnego w UE. Jest on w dalszym ciągu zdominowany przez przedstawicieli rządów państw członkowskich, ale parlamenty narodowe uzyskały nową funkcję ,strażnika zasady pomocniczości”. Co prawda efektem takiej sygnalizacji niezgodności z zasadą pomocniczości jest jedynie poddanie sprawy ponownej analizie, a Komisja może podtrzymać swe dotychczasowe stanowisko, to jednak zastrzeżenia, które uzyskałyby tak istotny zasięg, nie mogłyby być zlekceważone. Dopiero jednak praktyka stosowania tej reguły pokaże, jak często i z jakim skutkiem parlamenty narodowe będą sięgały po ten instrument, ryzykując napięcie w stosunkach z Komisją Europejską. Wtedy też będzie można dokonać pogłębionej analizy faktycznego znaczenia tej innowacji ustrojowej.

\section{PROBLEMY PRAKTYCZNEGO WDRAŻANIA ROLI PARLAMENTÓW NARODOWYCH JAKO STRAŻNIKA ZASADY POMOCNICZOŚCI W KONTEKŚCIE ROLI PARLAMENTÓW NARODOWYCH W UNIJNYCH PROCESACH DECYZYJNYCH}

Zasadniczą kwestią jest to, jaką szansę mają parlamenty narodowe, by efektywnie wykorzystać przyznane im kompetencje. Nie ma tu jeszcze kompleksowych badań, które ukazywałyby precyzyjny obraz tego zjawiska ${ }^{56}$. Doświadczenia krajów członkowskich UE przynoszą tu jednak interesujące obserwacje. Choć np. Szwecja i Finlandia przystąpiły do UE w ramach tej samej fazy rozszerzenia i mają porównywalne systemy polityczne, to jednak rola parlamentu fińskiego w sprawach integracji europejskiej jest silna, podczas gdy parlament szwedzki czuje się w tych sprawach zmarginalizowany ${ }^{57}$. Poważnym wyzwaniem staje się dla parlamentów narodowych kontrola polityki zagranicznej. Jak

55 A. Cygan, National Parliaments within EU Polity: No Longer Loosers but Hardly Victorious, "ERA-Forum: Scripta Iuris Europaei” 2012, nr 4, s. 517.

56 Zob. T. Winzen, National Parliamentary Control of the European Union Affairs: a CrossNational and Longitudinal Comparison, "West European Politics" 2012, nr 3, s. 658.

57 Zob. S. Ahlbäck Öberg, A.-C. Jungar, The Influence of National Parliaments over Domestic European Union Policies, "Scandinavian Political Studies" 2009, nr 4, s. 379. 
wskazują badania przeprowadzone we Włoszech i w Wielkiej Brytanii, czynnikiem osłabiającym parlamenty narodowe jest nie tylko brak informacji od rządów i doświadczenia w zakresie procesów integracji europejskiej, ale też zakres szybko rozwijającej się współpracy międzyrządowej, który powoduje, że efektywna kontrola parlamentarna $\mathrm{w}$ tej skali staje się praktycznie niemożliwa ${ }^{58}$. Z kolei doświadczenia parlamentów we Francji i w Niemczech wskazują, że uprawnienia kontrolne parlamentów narodowych mogą okazać się efektywne, jeśli są realizowane w sposób adekwatny do mechanizmów funkcjonowania UE, które w układzie krajowym są charakterystyczne dla działań opozycji ${ }^{59}$. Znaczenie ma też to, czy funkcje kontrolne wykonywane są ex ante, są wówczas mniej widoczne i bardziej politycznie zorientowane (jak w Danii), czy ex post, są wówczas bardziej widoczne (jak w Holandii ${ }^{60}$. Z przeprowadzonych badań wynika, że czynnikiem osłabiającym wpływ parlamentów narodowych jest przekaz medialny procedur decyzyjnych w Unii, który nastawiony jest na sugerowanie dominacji władzy wykonawczej, zwłaszcza gdy ma miejsce ograniczony przekaz medialny tego, co dzieje się w Unii ${ }^{61}$.

Poważnym wyzwaniem dla parlamentów narodowych jest również to, jak formułować opinie dotyczące naruszenia zasady pomocniczości ${ }^{62}$ oraz $\mathrm{w}$ jaki praktyczny sposób osiągnąć porozumienie na poziomie $1 / 3$ lub $1 / 4$, niezbędne w przypadku realizowani procedury „,wczesnego ostrzegania” w ramach kontroli realizacji zasady pomocniczości. $\mathrm{Z}$ tego punktu widzenia tego godnym analizy jest Raport w sprawie wyników prac grupy roboczej przedstawicieli parlamentów narodowych przy UE ds. wprowadzenia w życie Protokołu $n \mathrm{nr}$ $w$ sprawie stosowania zasad pomocniczości i proporcjonalności, dołaczonego do Traktatu z Lizbony ${ }^{63}$ (dalej: Raport). Dokument ten ukazuje bowiem, jak

58 Zob. F. Zanon, EU Foreign Policy Cooperation: a Challenge for National Parliaments?, "European Foreign Affairs Review" 2010, nr 1, s. 23.

59 Zob. K. Sprung, Ever More Or Ever Better Scrutiny?: Analysisng the Conditions of Effective National Parliamentary Involvement in EU Affairs, EIOP 2010, $\mathrm{nr} 2$.

60 Zob. P. de Wilde, Ex Ante vs. Ex Post: the Trade-off between Partisan Conflict and Visibility in Debating EU Policy-Formulation in National Parliaments, "Journal of European Public Policy" 2011, nr 5, s. 675.

${ }^{61}$ Zob. P. de Wilde, No Effect, Weapon of the Weak Or Reinforcing Executive Dominance?: How Media Coverage Affects National Parliaments's Involvement in EU Policy-Formulation, Comparative European Politics" 2011, nr 2, s. 137.

62 Zob. P. Kiiver, The Conduct of Subsidiarity Checks of EU Legislative Proposals by National Parliaments" Analysis, Observation and Practical Recommendation, "ERA-Forum: Scripta Iuris Europaei” 2012, nr 4, s. 358.

${ }^{63}$ Zob. Dziesiaty raport pótroczny: zmiany stosowanych w Unii Europejskiej procedur i praktyk dotyczacych kontroli parlamentarnej, przygotowany przez. Sekretariat COSAC przedstawiony na 
parlamenty narodowe postrzegają system realizacji uprawnień, przyznanych im przez Traktat z Lizbony ${ }^{64}$.

Raport ten jest wynikiem prac grupy roboczej przedstawicieli parlamentów narodowych przy UE, utworzonej podczas XXXIX spotkania COSAC, które odbyło się w dniach 7-8 maja 2008 roku w miejscowości Brdo pri Kranju w okresie prezydencji słoweńskiej ${ }^{65}$. COSAC wezwał wówczas prezydencję francuską, by opracowała listę pomysłów przedstawionych przez parlamenty narodowe, jak ulepszyć współpracę przy realizacji Protokołu nr $2 \mathrm{w}$ sprawie stosowania zasad pomocniczości i proporcjonalności. Wezwał też prezydencję francuską, by zaprosiła grupę roboczą, składającą się z przedstawicieli parlamentów narodowych przy UE, której praca będzie podstawą do opracowania raportu na temat tego, w jaki sposób parlamenty narodowe mogą wykorzystać te pomysły oraz tego, czy będą potrzebne wspólne przygotowania przy jednoczesnym poszanowaniu prawa każdego parlamentu do decydowania o własnym trybie pracy. Na podstawie tego mandatu prezydencja francuska zaprosiła grupę roboczą przedstawicieli parlamentów narodowych przy UE. Grupa ta składała się z 41 członków reprezentujących parlamenty narodowe lub ich izby. Przewodniczyli jej przedstawiciele parlamentu francuskiego: Anne Marquant, reprezentująca Senat oraz Frank Baron, reprezentujący Zgromadzenie Narodowe.

Parlamenty narodowe uważają - jak głosi Raport (s. 19) - że najlepszym sposobem współpracy jest wzajemne informowanie się, na jak najwcześniejszym etapie, o tekstach aktów ustawodawczych, które zamierzają poddać kontroli pod kątem zgodności z zasadą pomocniczości przed przyjęciem oficjalnego stanowiska. Dotyczyłoby to propozycji wybranych w drodze analizy programu legislacyjnego i prac Komisji Europejskiej lub w inny sposób, jak również wszystkich innych propozycji, które przyciągnęły uwagę parlamentu narodowego przy ich przyjmowaniu przez Komisję Europejską. Celem wczesnej wymiany informacji ma być zawiadomienie innych parlamentów narodowych przed upływem terminu, o którym mowa w Protokole nr 2 do Traktatu z Lizbony.

XL Konferencji Komisji Wyspecjalizowanych w Sprawach Wspólnotowych i Europejskich Parlamentów Unii Europejskiej, Paryż, 3-4 listopada 2008 r., s. 17 i n.

${ }^{64}$ Zob. J. Jaskiernia, Członkostwo Polski w Unii Europejskiej a problem efektywności oddziaływania parlamentu narodowego na proces tworzenia prawa w UE [w:] Polska w strukturach Unii Europejskiej: Doświadczenia - oczekiwania - wyzwania, red. M. Marczewska-Rytko, Wydawnictwo Uniwersytetu Marii Curie-Skłodowskiej, Lublin 2010, s. 142 i nast..

${ }^{65}$ Zob. Dziewiąy raport pótroczny: zmiany stosowanych $w$ Unii Europejskiej procedur $i$ praktyk dotyczacych kontroli parlamentarnej, przygotowany przez Sekretariat COSAC przedstawiony na XXXIX Konferencji Komisji Wyspecjalizowanych w Sprawach Wspólnotowych i Europejskich Parlamentów Unii Europejskiej, Bled - Brdo pri Kranju, 7-8 maja 2008 r., s. 5. 
Parlamenty narodowe mogłyby wówczas dokonać wspólnej refleksji na temat zasady pomocniczości, początkowo w formie seminariów ekspertów parlamentów narodowych w sprawie wprowadzania w życie wniosków prezydencji Konferencji Parlamentów Unii Europejskiej, która odbyła się w Lizbonie w 2008 r. Przyjęto wówczas następujące postanowienie: „Przewodniczący, biorąc pod uwagę prace grupy roboczej COSAC, uważają za właściwe rozpoczęcie wspólnej refleksji w odniesieniu do kryteriów i procedur w sprawie wdrażania nowych uprawnień przyznanych parlamentom narodowym przez Traktat z Lizbony, tak, aby zostały one wdrożone, gdy tylko postęp procesu ratyfikacyjnego na to pozwoli. W związku z tym przewodniczący mają nadzieję, że będzie możliwe ustanowienie owocnego dialogu z instytucji europejskimi w tych sprawach".

Wczesne przekazywanie informacji innym parlamentom narodowym powinno być rozszerzone na dokumentację, w tym na dokumenty konsultacyjne wytypowane do przeprowadzania dogłębnej analizy pod kątem innych kwestii niż zasada pomocniczości, w ramach dialogu politycznego, rozpoczętego z inicjatywy przewodniczącego Komisji Europejskiej, José Manuela Barroso oraz z uwzględnieniem w szczególności analizy dokumentacji pod kątem zgodności z zasadą proporcjonalności i przesłanek merytorycznych.

Nie ulega więc wątpliwości, że dostrzegana jest potrzeba wprowadzenia skutecznego mechanizmu konsultacji. Zarazem jednak parlamenty narodowe postępują tu ostrożnie, zachęcając do „wspólnej refleksji”, gdyż zdają sobie sprawę, że w obszarze tak delikatnym politycznie trudno będzie znaleźć rozwiązania w drodze konsensu.

Wszystkie parlamenty narodowe uważają, jak podkreślono w Raporcie (s. 19-20), że system IPEX jest najbardziej właściwym forum do przekazywania informacji o oficjalnych decyzjach parlamentów narodowych na temat zgodności z zasadą pomocniczości. Zdaniem tych parlamentów, najlepszą praktyką jest opracowywanie przynajmniej streszczenia, w języku angielskim lub francuskim, każdej przyjmowanej przez siebie „uzasadnionej decyzji” (użycie pojęcia „uzasadniona decyzja” ma tu oznaczać, jak się wydaje, że decyzja powinna mieć uzasadnienie, a nie to, że jest uzasadniona w rozumieniu „zasadna” czy „prawidłowa”) ${ }^{66}$. Bardzo przydatnym rozwiązaniem byłoby wykorzystanie istniejącej funkcji subskrypcji w ramach systemu IPEX do stworzenia systemu zawiadomień ostrzegawczych przesyłanych pocztą elektroniczną do wszystkich

${ }^{66}$ Zob. J. Jaskiernia, Recenzja z książki: J. Barcz, M. Górka, A. Wyrozumska, „Instytucje i prawo Unii Europejskiej. Podręcznik dla kierunków zarządzania i administracji, Warszawa 2008, „Europejski Przegląd Sądowy” 2009, nr 2, s. 59. 
zainteresowanych użytkowników w przypadku, gdy tekst jest przedmiotem „uzasadnionej opinii”.

Parlamenty narodowe uważają, że należy w pełni wykorzystać funkcje systemu IPEX celem lepszego uwzględnienia potrzeb wczesnej wymiany informacji między parlamentami narodowymi. Przydatny do tego jest istniejący symbol oznaczający aspekty pomocniczości lub proporcjonalności, a także symbol dotyczący „ważnych informacji podlegających wymianie”. Sygnały te byłyby aktualizowane po zakończeniu kontroli przez dany parlament narodowy z chwilą przyjęcia oficjalnego stanowiska, lub byłyby usuwane w przypadku, gdyby parlament postanowił nie podejmować interwencji. Zarząd IPEX postanowił już wprowadzić nowy symbol oznaczający przyjęcie ,uzasadnionej opinii” przez parlamenty narodowe.

Parlamenty narodowe uważają, że po zasięgnięciu opinii użytkowników, Zarząd IPEX powinien propagować powszechne stosowanie tych symboli w serwisie IPEX. Parlamenty narodowe mogłyby sporządzić listę adresatów poczty elektronicznej, celem ułatwienia kontaktu z osobami zajmującymi się wymianą informacji, w przypadku, gdy tekst Komisji Europejskiej jest powiązany z jedną lub kilkoma „uzasadnionymi opiniami”. Przedstawiciele parlamentów narodowych w Brukseli mogliby się spotykać w celu wymiany informacji na temat wybranych tekstów lub tekstów podlegających kontroli. Spotkania te odbywałyby się regularnie, aby można było wymienić informacje na tematy związane ze stosowaniem zasady pomocniczości. Można by też opracować zestawienia wszelkich tekstów, w przypadku których parlamenty narodowe zgłosiły możliwość wystąpienia problemu z punktu widzenia zasady pomocniczości oraz przekazywać to zestawienie nie później niż na dwa tygodnie przed wygaśnięciem ośmiotygodniowego okresu analizy, aby umożliwić uwzględnienie opinii parlamentów narodowych. Parlamenty narodowe zastrzegły jednak, że wczesne sygnały zamieszczone w serwisie IPEX, informacje przesyłane pocztą elektroniczną lub prezentowane na spotkaniu w Brukseli nie będą uważane za oficjalne stanowisko parlamentu narodowego, w przypadku braku decyzji politycznej podjętej przez organy tego parlamentu.

Rodzi się jednak pytanie, czy przewidziany tu sześciotygodniowy termin nie jest byt długi. Dwa tygodnie pozostawione pozostałym parlamentom narodowym na decyzje mogą okazać się okresem zbyt krótkim, by przeprowadzić stosowna procedurę. 


\section{PROBLEM KONIECZNYCH ZMIAN W PRAWIE PARLAMENTARNYM WOBEC NOWEJ ROLI PARLAMENTÓW NARODOWYCH W UNII EUROPEJSKIEJ}

Nie ulega wątpliwości, że realizacja nowych uprawnień parlamentów narodowych będzie niosła potrzebę dokonania zmian w prawie parlamentarnym. Jeśli chodzi o system prawny RP, to częściowo zmiany te już zostały dokonane. W bezpośrednim związku z akcesją RP do Unii Europejskiej pozostawała ustawa z 11 III 2004 r. w współpracy Rady Ministrów z Sejmem i Senatem w sprawach związanych z członkostwem Rzeczypospolitej Polskiej w Unii Europejskiej ${ }^{67}$. Towarzyszyły jej zmiany w regulaminie Sejmu, poprzez wprowadzenie rozdz. 5a „Postępowanie z projektami ustaw wykonującymi prawo Unii Europejskiej” oraz dodanie rozdz. 13a „Komisja ds. Unii Europejskiej” ${ }^{68}$ oraz w regulaminie Senatu, przewidujące m.in. powołanie Komisji Spraw Unii Europejskiej ${ }^{69}$.

Natomiast konsekwencją wejścia w życie Traktatu z Lizbony stała się ustawa z 8 X 2010 r. o współpracy Rady Ministrów z Sejmem i Senatem w sprawach związanych z członkowstwem Polski w Unii Europejskiej ${ }^{70}$. Stosowne zmiany zostały też wprowadzone w regulaminie Sejmu. M. in. Komisja do spraw Unii Europejskiej dokonywać będzie wstępnej oceny zgodności aktów ustawodawczych Unii Europejskiej z zasadą pomocniczości. Uzyskanie nowych uprawnień przez Sejm i Senat, w konsekwencji wejścia w życie tego traktatu, wymagać będzie jednak zmiany w Konstytucji $\mathrm{RP}^{71}$.

Sprawą kluczową staje się zinstytucjonalizowane skoordynowanie procedury „wczesnego ostrzegania” w ramach badania zgodności aktów ustawodawczych z zasadą pomocniczości. Niezależnie od aktywności innych struktur (zwłaszcza COSAC) muszą być stworzone (bądź zmodyfikowane) parlamentarne procedury,

${ }^{67}$ Dz.U. Nr 52, poz. 515. Por. W. Sokolewicz, Formy oddziaływania parlamentu na prawotwórstwo Unii Europejskiej, „Państwo i Prawo” 2004, nr 8, s. 4. Por. J. Jaskiernia, Członkostwo Polski w Unii Europejskiej a konstytucyjne organy władzy publicznej, [w:] P. Chmielnicki (red.), Konstytucyjny system władz publicznych, LexisNexis, wyd. 2, Warszawa 2010, s. 353.

${ }^{68}$ Uchwala Sejmu RPP z 20 II 2004 roku o zmianie Regulaminu Sejmu RP (M.P. Nr 12, poz. 182)

${ }^{69}$ Uchwała Senatu RP z 22 IV 2004 roku w sprawie zmiany regulaminu Senatu RP (N.P. Nr 18, poz. 302)

70 Dz.U. Nr 213, poz. 1395. Zob. A. Pudło, Rola drugich izb parlamentów państw członkowskich $w$ sprawach Unii Europejskiej w świetle regulacji krajowych $i$ unijnych, Instytut Wydawniczy EuroPrawo, Warszawa 2011, s. 294.

71 Zob. J. Marszałek-Kawa, Pozycja ustrojowa i funkcje Sejmu Rzeczypospolitej Polskiej po akcesji do Unii Europejskiej, Dom Wydawniczy ELIPSA, Warszawa 2012, s. 274. 
które umożliwią efektywną koordynację międzyparlamentarną. Bez takiej instytucjonalizacji, uwzględniającej reguły, mechanizmy i terminy, bardzo trudno będzie uzyskać efekt w postaci uzgodnień parlamentarnych na poziomie $\frac{1}{3}$ lub $1 \frac{1}{4}$ poparcia, wymaganych przy próbie skutecznego wymuszenia na Komisji ponownego przeanalizowania projektów. Przeprowadzone z inicjatywy COSAC, podjętej na XXXII spotkaniu w Hadze w 2004 r., pilotażowe testy korzystania przez parlamenty państw członkowskich z instrumentów wywierania wpływu na kształt prawa europejskiego pokazały, że jest to trudne wyzwanie dla parlamentów narodowych, wymagające odpowiedniego przygotowania parlamentarzystów, a także służb doradczo-administracyjnych do realizacji takich kompetencji ${ }^{72}$.

Istotną kwestią jest też sprecyzowanie, na poziomie prawa parlamentarnego, jak ma przebiegać kontrola parlamentów narodowych w ramach przestrzeni Wolności, Bezpieczeństwa i Sprawiedliwości. Parlamenty narodowe otrzymały tu m.in. prawo do kontroli Eurojustu i Europolu. Hipotetycznie są to bardzo ważne uprawnienia, ale ich praktyczna realizacja będzie utrudniona, skoro nie zostały sprecyzowane dotychczas w dokumentach unijnych reguły tej kontroli. Najpierw więc będą musiały być wydane stosowne akty prawa wtórnego, a - niejako w ich konsekwencji - powinny być sprecyzowane reguły na poziomie prawa parlamentarnego. W przeciwnym razie kontrola sprowadzona by została do otrzymywania dokumentów, co w istotny sposób zubożałoby sens i oczekiwania związane z tym uprawnieniem, zwłaszcza w kontekście ograniczania „deficytu demokracji”.

Wskazuje się ponadto, że pełne dostosowanie parlamentów narodowych do nowych kompetencji będzie wiązało się z potrzebą szerszego wykorzystania nowoczesnych technik elektronicznych, takich jak e-government czy e-justice, by parlament narodowy rzeczywiście miały możliwość realizacji uprawnień kontrolnych, jakie dał im Traktat z Lizbony ${ }^{73}$. Wiąże się to z szerszym problemem: w jakim stopniu parlamenty narodowe są logistyczne (m.in. sposób procedowania z ogromną liczbą dokumentów unijnych) i intelektualnie (zaplecze badawcze, niezależne od władzy wykonawczej zespoły ekspertów) przygotowane do realizacji nowych zadań. Może się okazać, że konieczne będzie - jak to zrobił niemiecki Bundestag ${ }^{74}$ - otwieranie biur parlamentów narodowych w Brukseli, by podołać nowym zadaniom, jakie otrzymały one na podstawie Traktatu z Lizbony.

72 Zob. E. Popławska, Rola parlamentów narodowych w Unii Europejskiej - aspiracje a rzeczywistość, „Studia Prawnicze” 2006, nr 3, s. 106 i nast.

73 Zob. J. Lodge, E-government, Scrutiny and Liberty in the EU: a Role for the National Parliaments?, "Romanian Journal of European Affairs" 2009, nr 2, s. 7.

74 Zob. T. Beicheld, Recovering Space Lost?: The German Bundestag's New Potential in European Politics, "German Politics" 2012, nr 2, s. 149. 


\section{UWAGI KOŃCOWE}

W świetle przeprowadzonej analizy nie ulega wątpliwości, że Traktat z Lizbony stanowi ważny impuls w zakresie umocnienia roli parlamentów narodowych w unijnym procesie decyzyjnym, a szerzej - w procesie integracji europejskiej. Wprowadzenie mechanizmu „wczesnego ostrzegania” w procesie badania zgodności aktów ustawodawczych UE z zasadą pomocniczości otwiera niewątpliwie nowe możliwości oddziaływania na unijny proces prawotwórczy. Przyznanie parlamentom narodowym uprawnień kontrolnych w Przestrzeni Wolności, Bezpieczeństwa i Sprawiedliwości, m.in. w odniesieniu do Eurojustu i Europolu, otwiera nowe możliwości realizacji funkcji kontrolnej. Są to więc posunięcia, które powinny ograniczać „,deficyt demokracji”, rzucający cień na legitymizację demokratyczną Unii. Należy jednak dostrzegać ograniczone znaczenie tych posunięć. Badanie zgodności aktów ustawodawczych z zasadą pomocniczości jest tylko jednym $\mathrm{z}$ aspektów procesu prawotwórczego, choć mającego jednak istotny wymiar symboliczny w kontekście stawiania barier do nadmiernego rozszerzania kompetencji Unii kosztem parlamentów narodowych. Nie oznacza on jednak szerszego dopuszczenia parlamentów narodowych do głównego nurtu procesów prawotwórczych. Z kolei ważne uprawnienia kontrolne w Przestrzeni Wolności, Bezpieczeństwa i Sprawiedliwości niejako „zawisły w próżni”, wobec braku aktów wykonawczych. Dopiero więc przyszłość pokaże, czy nowe uprawnienia, przyznane parlamentom narodowym przez Traktat z Lizbony, stworzyły rzeczywisty przełom. Wiele zależeć będzie od tego, czy parlamenty narodowe zdołają dostosować swe mechanizmy działania do nowych wyzwań, jakie niesie proces integracji europejskiej.

Summary

\section{ROLE OF THE NATIONAL PARLIAMENTS IN THE PROCESS OF EUROPEAN INTEGRATION AFTER TREATY OF LISBON AND THE NECESSARY CHANGES IN PARLIAMENTARY LAW}

The author analyses the role of the national parliaments in the process of European Integration. Treaty of Lisbon has offered new competences to the national parliaments. They may control legislative proposals of the Commission in the context of fulfilling the principle of subsidiarity. This 'Early Warning System' has greatly extended the position of national parliament in EU decision-making procedure. In consequence, changes in 
parliamentary law have occurred or should be passed. However, real meaning of this new competences will depend on capacity of national parliaments to successfully perform that new rights. Especially important is coordination with other national parliaments to achieve $1 / 3$ (or $1 / 4$ majority) level of protest upon which the Commission should rethink a legislative proposal. Useful forum should be the COSAC, but bilateral cooperation will be as well necessary. Important competences also arrived to national parliament in the Area of Freedom, Security and Justice (e.g. controlling of the Eurojust and the Europol), but the new EU regulations are necessary to perform these functions. Strengthening the position of national parliaments should reduce, in theory, "democratic deficit' in EU, but whether it will occur depends on how effectively national parliaments will use the new competences and extend real power in the EU decision-making system.

Keywords: Early Warning System; principle of subsidiarity; national parliaments; Treaty of Lisbon; EU decision-making procedure.

Riassunto

\section{IL RUOLO DEI PARLAMENTI NAZIONALI NEL PROCESSO DI INTEGRAZIONE EUROPEA ED I MUTAMENTI NEL DIRITTO PARLAMENTARE DOPO IL TRATTATO DI LISBONA}

L'autore prende in esame il ruolo dei parlamenti nazionali nel processo di integrazione Europea. Tra competenze loro affidate dal Trattato di Lisbona emerge il meccanismo di controllo di sussidiarietà, attraverso il quale verificano le proposte legislative delle Commissione. Questo sistema, definito di 'Allerta Precoce' (Early Warning System), ha ampliato notevolmente i poteri dei parlamenti nazionali, rafforzando il loro ruolo nel quadro del processo decisionale dell'UE. Di conseguenza si devono apportare modifiche nel diritto parlamentare, alcune delle quali si sono già verificate.

Tuttavia, l'impatto di questi poteri e competenze affidati ai parlamenti nazionali dipenderà dalla loro capacità di poterne disporre in modo efficiente. Particolare importanza riveste il coordinamento per raggiungere la soglia (quorum di $1 / 3 \mathrm{o}$, in alcuni casi, di $1 / 4$ dei voti attribuiti ai parlamenti nazioanli) per l'attivazione della protesta nei confronti della Comissione la quale comporta il suo riesame del progetto. La COSAC dovrebbe essere un forum opportuno, ma sarebbe necessario anche gettare le basi di una cooperazione bilaterale. Inoltre, le competenze dei parlamenti sono state estese nel campo della libertà, sicurezza e giustizia (ad esempio, controllo delle attività di Eurojust e Europol), ma per disporne sono indispensabili nuove normative. 
In teoria il rafforzamento dei poteri dei parlamenti nazionali dovrebbe contribuire a colmare il deficit democratico dell'Unione europea ma questo dipende dal loro ruolo assunto nell'assetto di decision-making dell'UE.

Tłumaczenie: K. Jachimowicz

Parola chiave: 'Allerta Precoce'; di controllo di sussidiarietà; parlamenti nazionali; Trattato di Lisbona del processo decisionale dell'UE. 
